\title{
CASE COMMENT: VRIEND v. ALBERTA PLESSY REVISITED: LESBIAN AND GAY RIGHTS IN THE PROVINCE OF ALBERTA
}

\author{
SHANNON K. O'BYRNE and JAMES F. McGINNIS`
}

\section{INTRODUCTION}

The Alberta Court of Appeal, in Vriend v. Alberta, ${ }^{1}$ has recently ruled that the Alberta government's decision not to protect gays and lesbians from discrimination in such fundamental matters as employment and housing does not run afoul of the Canadian Charter of Rights and Freedoms. ${ }^{2}$ Instead, the court determined that the Alberta Individual's Rights Protection $\mathrm{Act}^{3}$ - while offering protection from discrimination based on many grounds including race, religious beliefs, colour, and gender - was not constitutionally deficient for being under-inclusive. As Mr. Justice McClung states in the lead decision:

I cannot agree that the deliberate legislative omission of the words "sexual orientation" in the IRPA ... when held up against the Canadian Charter of Rights and Freedoms, leads inexorably to the constitutional infirmity of such a statute.... Of course, responding in this way carries political risk. In time the government will have to answer to the highest court of public policy, tomorrow's ballot-box. ${ }^{4}$

Regrettably, McClung J.A.'s decision is an exercise in misplaced judicial deference and legislative apology wherein he propounds the virtue of leaving the determination of lesbian and gay rights squarely with the legislature. With respect, such an attitude in the face of governmentally-sanctioned human rights violations is as profound an abdication of judicial responsibility as was witnessed in such notorious 19th century American constitutional decisions as Plessy v. Ferguson, ${ }^{5}$ and Dred Scott v. Sandford. ${ }^{6}$

The purpose of this article is to explore how McClung J.A. legitimizes judicial inaction in the context of discrimination against homosexuals by identifying the ways which he reasons backwards from a conclusion favouring the government of Alberta. Part I provides the legislative and factual context of the decision. Part II considers the methods used by McClung J.A. to justify his strategically insular view of human rights.

\footnotetext{
- Shannon Kathleen O'Byme, Assistant Professor, Faculty of Law, University of Alberta and James F. McGinnis, Barrister and Solicitor, Parlee McLaws, Edmonton, AB. The authors would like to thank Professor David Schneiderman, Executive Director of the Centre for Constitutional Studies and Professor Wayne Renke for their very helpful comments on an earlier version of this article as well as Ms. Katherine Burt for her research assistance.

1 (23 February 1996), Edmonton 9403-0380 (Alta. C.A.) [hereinater Vriend].

2 Part 1 of the Constitution Act, 1982, being Schedule B to the Canada Act 1982 (U.K.), 1982, c. 11 [hereinafter Charter].

3 R.S.A. 1980, c. I-2 [hereinafter IRPA].

1 Supra note 1 at 39-40.

s 163 U.S. 537 (1896) [hereinafter Plessy].

619 How. 393 (1856) [hereinafter Dred Scott].
} 
These include: placing an undue emphasis on judicial passivism and historical deference; recasting the question of human rights for the homosexual community as a moral issue; exaggerating the actual scope of Vriend's legislative expectations; recommending the Alberta government's "compromise" position regarding lesbian and gay rights contained in the $I R P A$; taking a very limited view as to what counts as government action; attempting to revive the long discredited Bliss v. Attorney General of Canada ${ }^{7}$ approach to determining whether a piece of legislation is discriminatory or not; as well as alluding purposefully to the potential difficulties in defining "sexual orientation" and the absence of evidence before the court of discrimination against homosexuals. ${ }^{8}$ It will be seen that Mr. Justice McClung's analysis - because it is primarily driven by the values reflected in obsolete judicial decisions regarding the role of the state and judiciary - is thereby ill-equipped to address human rights violations experienced by the applicant in Vriend.

\section{THE LEGISLATIVE AND FACTUAL CONTEXT}

There has never been legislation in Alberta protecting the rights of gays and lesbians in the private sector. The IRPA does prohibit discrimination in employment on the grounds of "race, religious beliefs, colour, gender, physical disability, mental disability, marital status, age, ancestry or place of origin...." It also prohibits discrimination in the provision of accommodation, services or facilities "customarily available to the public" on the grounds of "race, religious beliefs, colour, gender, physical disability, mental disability, ancestry or place of origin...." ${ }^{10}$ However, there is no express prohibition of any kind of discrimination on the grounds of sexual orientation."

This deficiency has been objected to not only by members and supporters of the lesbian and gay community, but also by representatives in the Alberta Legislative Assembly. In fact, between 1986 and 1992, opposition members introduced bills on six separate occasions seeking to amend the IRPA to include sexual orientation in its list of prohibited grounds. ${ }^{12}$ Each of the six bills were voted down by the Progressive Conservative government, which has held the majority of seats in the Legislature since 1971.

[1979] 1 S.C.R. 183 [hereinafter Bliss].

Several of these topics are addressed in other articles contained in this issue.

Supra note 3, s. $7(1)$.

Ibid., s. 3.

Ibid. Sections 3 and 4 of the IRPA respectively prohibit discrimination in public accommodation and tenancy because of "race, religious beliefs, colour, gender, physical disability, mental disability, ancestry or place of origin." Sections $7(1)$ and 10 , respectively, prohibit discrimination in employment and membership in trade unions because of "race, religious beliefs, colour, gender, physical disability, mental disability, marital status, age ancestry or place of origin."

See the Factum of the Appellant in Vriend as well as the trial judge's commentary in Vriend $\mathbf{v}$. Alberta, [1994] 6 W.W.R. 414 (Alta. Q.B.) at 419 [hereinafter Vriend (Q.B.)]. It is also significant to note that the government's decision not to extend the reach of the IRPA was contrary to the recommendations of the Alberta Human Rights Commission, Gay and Lesbian Awareness Society of Edmonton, Calgary Lesbian and Gay Political Action Guild, Gay Lines of Calgary, A Study of Discrimination Based on Sexual Orientation (Edmonton, 1992). 
It was within this legislative context that Mr. Delwin Vriend began his employment as a laboratory co-ordinator with King's College - a Christian, post-secondary institution - in Edmonton, Alberta, in 1987. Though a competent employee, he was fired in 1991 when he admitted to being homosexual upon being confronted with the question by the College president. ${ }^{13}$ The sole reason for his termination was noncompliance with the policy of the College concerning homosexual practice. ${ }^{14}$

Five months later, Vriend made complaint to the Alberta Human Rights Commission (the "Commission"), a body constituted and mandated under the IRPA to investigate complaints of discrimination within its jurisdiction. ${ }^{15}$ In Vriend's view, it was contrary to the IRPA to be fired on the grounds of homosexuality. The Commission disagreed, however, and on July 10,1991, it advised Vriend that his complaint would not be investigated because sexual orientation was not a protected ground under the IRPA. Accordingly, the Commission had no jurisdiction to proceed.

Vriend's next step was to apply to the Alberta Court of Queen's Bench for a declaration that those provisions in the IRPA which did not expressly include sexual orientation as a prohibited ground of discrimination were contrary to the Charter and for an order directing the Commission to hear his complaint.

Vriend's argument, based on Haig v. Canada, ${ }^{16}$ was simply this: The IPRA, being a piece of legislation and hence captured by s. 32(1)(b) of the Charter, is constitutionally invalid to the extent that it violates the $\mathrm{s}$. 15 equality provision of the Charter. The equality provision is violated because the IRPA fails to extend protection against discrimination to homosexuals while according it to others such as racial minority groups.

Vriend was successful before Madam Justice Russell of the Alberta Court of Queen's Bench (now of the Alberta Court of Appeal), thereby permitting him to file a human rights complaint against his former employer. Russell $\mathrm{J}$. held that the IRPA infringed s. 15(1) of the Charter for failure to include sexual orientation as a prohibited ground of discrimination:

Regardless of whether there was any intent to discriminate, the effect of the decision to deny homosexuals recognition under the legislation is to reinforce negative stereotyping and prejudice thereby perpetuating and implicitly condoning its occurrence. The facts in this case demonstrate that the legislation had a differential impact on the applicant Vriend. When his employment was terminated because of his personal characteristics he was denied a legal remedy available to other similarly disadvantaged groups. That constitutes discrimination contrary to s. $15(1)$ of the Charter. ${ }^{17}$

Vriend (Q.B.), ibid.

lbid.

See IRPA, supra note 3, ss. 14(1), 20(1).

(1992), 94 D.L.R. (4th) 1 (Ont. C.A.) [hereinafter Haig].

Vriend (Q.B.), supra note 12 at 431 . 
Having found this breach not justifiable under s. 1, her Ladyship deployed the remedy of "reading in," by granting an order that the IRPA be read as if it did expressly prohibit discrimination on the ground of sexual orientation. This meant that the Commission would have to review Vriend's complaint, make its investigation, hear argument and rule on the matters in issue. If the facts were as Vriend alleged, the Commission would then have to determine whether the College's policy to fire those who violated its views regarding homosexuality could, in turn, survive scrutiny under the IRPA. ${ }^{18}$

The Alberta Court of Appeal, in the lead decision of Mr. Justice McClung, ${ }^{19}$ reversed the decision of Russell $\mathrm{J}$. on the basis that the Alberta legislation is not discriminatory on its face nor in its effect as it treats homosexuals and heterosexuals alike, nor does its silence count as government action. His Lordship also noted that judicial deference was to be paid to the fact that the Alberta legislature had not wanted to include protection of sexual orientation in the IRPA, and in fact went to considerable lengths to prevent its inclusion. ${ }^{20}$

Counsel for Vriend is currently seeking leave to appeal this decision to the Supreme Court of Canada. ${ }^{21}$

\section{JUDICIAL STRATEGIES TO JUSTIFY AN INSULAR VIEW OF HUMAN RIGHTS}

\section{A. INTRODUCTION}

One can detect in Mr. Justice McClung's Reasons for Judgment a series of strategies through which he seeks to justify judicial inaction in the face of human rights violations experienced by Vriend as an individual and homosexuals as a group. This section of the article explores these strategies seriatim.

As a preliminary matter, it is important to note that disabling provisions constraining parliamentary sovereignty - such as those in the Canadian and American Constitutions - generate one of the more long-standing debates in the theory and practice of democracy, a debate which is very much present in the decision of McClung J.A. The charge that enforcement of constitutional disabling provisions is contrary to the

There are two provisions in the IRPA which King's College could attempt to invoke in order to defend its policy regarding homosexuality: Section $7(3)$ allows discrimination in employment practices if the discrimination is "based on a bona fide occupational requirement." Section 11.1 states: "A contravention of this Act shall be deemed not to have occurred if the person who is alleged to have contravened the Act shows that the alleged contravention was reasonable and justifiable in the circumstances." reasons parallel his to the extent that I have also concluded that the Individual Rights Protection Act ("IRPA") does not create a distinction based on sexual orientation" at 1 of his Reasons for Judgment. Madam Justice Hunt dissented.

21 Counsel of record, on appeal, is Ms. Sheila Greckol of the Edmonton law firm of Chivers, Greckol \& Kanee. 
majoritarian principles of democracy has elicited at least four standard responses, according to Ronald Dworkin ${ }^{22}$ and each with its own infirmities. Dworkin's analysis of these responses is set out in the following chart: ${ }^{23}$

\begin{tabular}{|c|c|c|}
\hline $\begin{array}{l}\text { RESPONSE TO THE } \\
\text { PROPOSITION THAT JUDICIAL } \\
\text { REVIEW IS UNDEMOCRATIC }\end{array}$ & MAJOR ARGUMENT & DEFECT \\
\hline Defiance & $\begin{array}{l}\text { Protecting individual rights is } \\
\text { more important than the } \\
\text { principle of majority rule. }\end{array}$ & $\begin{array}{l}\text { It suggests that it is } \\
\text { inherently valid to compromise } \\
\text { democratic values. } \\
\text { It replaces democracy with } \\
\text { elitism because the judiciary } \\
\text { determines what rights to } \\
\text { respect, rather than the } \\
\text { community. }\end{array}$ \\
\hline Historical Deference & $\begin{array}{l}\text { The Constitution can only } \\
\text { disable majority rule to the } \\
\text { extent "actually and concretely } \\
\text { intended by past majorities - } \\
\text { the super-majorities who } \\
\text { enacted the provisions in the } \\
\text { first place." }\end{array}$ & $\begin{array}{l}\text { It produces "an extremely } \\
\text { conservative, even antiquated } \\
\text { constitution which favors } \\
\text { established political and } \\
\text { economic arrangements." } \\
\text { It is inconsistent with } \\
\text { impressive historical evidence } \\
\text { that "the founding statesmen } \\
\text { did not intend their own } \\
\text { views...to be decisive in } \\
\text { interpreting the Constitution. }\end{array}$ \\
\hline Passivism & $\begin{array}{l}\text { The judiciary should } \\
\text { functionally ignore the } \\
\text { disabling provisions "by } \\
\text { supposing them to give the } \\
\text { majority power to do anything } \\
\text { not patently irrational." }\end{array}$ & $\begin{array}{l}\text { The Constitution is a central } \\
\text { part of the law and should not } \\
\text { be ignored. }\end{array}$ \\
\hline Structuralism & $\begin{array}{l}\text { Disabling provisions do not } \\
\text { impair democracy but are } \\
\text { necessary to its creation and } \\
\text { maintenance. }\end{array}$ & $\begin{array}{l}\text { Only certain disabling } \\
\text { provisions (such as freedom of } \\
\text { expression) are classified as } \\
\text { structural, rendering the } \\
\text { response under-inclusive. }\end{array}$ \\
\hline
\end{tabular}


Drawing on John Ely's work, ${ }^{24}$ Dworkin ultimately recommends a modified structural approach to the Constitution, one which acknowledges the disabling provisions of the Constitution and rejects the "awkward compromises" of defiance, historicism or passivism because "they deny our legal system integrity at the most fundamental level." ${ }^{.25}$

The next two sections below will explore the reasons given by Mr. Justice McClung for his deep reservations regarding judicial review and enforcement of constitutional disabling provisions. The extent to which these reasons fit within any of the categories identified above will also be considered. The balance of this part will identify Justice McClung's concomitant strategies for overturning the decision of Madam Justice Russell.

\section{B. MR. JUSTICE MCCLUNG'S THEORY OF JUDICIAL REVIEW}

\section{Passivism}

As already noted, McClung J.A. bases much of his decision in Vriend on the fact that the failure of the Alberta Legislature to include sexual orientation in the IRPA was not an oversight but, in fact, entirely intentional. On a related front, McClung J.A. notes that the issue of gay and lesbian rights is a divisive one in Alberta, with strong advocates for each point of view. On this basis, McClung, J.A. would not impeach the decision taken by government to "step back"26 from "a morally-eruptive social controversy"27 and do nothing at all. In fact, judicial deference is recommended by his Lordship, in a legion of references, as the appropriate response to such legislative silences.

Mr. Justice McClung indicates, for example, that latitude must be afforded the local law-makers to implement their powers. ${ }^{28}$ He notes the importance of allowing the "machinery of government ... a little play in its joints. ${ }^{.29} \mathrm{He}$ admonishes the judiciary to observe restraint in striking down "constitutionally assembled laws in favour of their own, substituting their vision of the ideal statute in place of that which has been democratically endorsed by the electors. ${ }^{130} \mathrm{He}$ adds: "The Order Paper of the Alberta Legislature is not to be dictated, even incidentally, by federally-appointed judges brandishing the Charter. ${ }^{31} \mathrm{He}$ also observes that:

J.H. Ely, Democracy and Distrust: A Theory of Judicial Review (Cambridge, Massachusetts:

Harvard University Press, 1980). See Dworkin's analysis of Ely, ibid. at 326.

2s Dworkin, ibid. at 344. See below for further discussion of Dworkin's analysis.

26 Supra note 1 at 19.

27 Ibid. at 13

28 Ibid. at 10

29 Ibid. at 27

30 Ibid. at 14

$31 \quad$ Ibid. at 15 
[o]ther declarations of the need for judicial self-restraint are easily assembled. Major J. was echoing Chambre J., two hundred years earlier, in Grigby v. Oakes (1801) 2 Bos. \& Pul. 526, 126 E.R. 1420, in which case the court discussed the pursuit of the perfect statute and cautioned, "...If the legislature has not gone far enough, it is for them, not for us, to remedy the defect." This proposition is fully tied to the general jurisprudence of Alberta, "...The responsibility to see that the statute law is just is on the Legislature, not on the Courts." Richert Co. v. Forbes, [1937] 3 W.W.R. 632 at 635 (Alta. App. Div., Harvey C.J.A.). Yet we judges insist on mechanically invading the legislative arena because human rights may be involved. Seemingly the nobility of the occasion now expiates the old judicial sin of repealing, even amending, legislation under the cloak of merely interpreting it. ${ }^{32}$

In sum: "We should remember that it is possible, just possible, that provincial legislatures can define and protect core Canadian values too. ${ }^{133}$

While it is true that judicial deference is an important part of the Canadian justice system and has been repeatedly affirmed by Justices of the Supreme Court of Canada, ${ }^{34}$ it is not a free-standing value nor can it be used to endorse passivism. Judicial deference is only appropriate when the Legislature has, in fact, acted in accordance with the Constitution. It is regrettable that Mr. Justice McClung's Reasons for Judgment display such a disturbing retrenchment from the role of the Canadian judiciary in protecting the human rights and dignity of all members of society.

McClung J.A.'s passivism to the legislators' will appears to be based on the view that - when it is all said and done - the legislative aspect of liberal democracy is paramount and it, above all other things, is worthy of scrupulous judicial protection. If this is his belief, it is misguided. The impetus to restrain legislative power and protect human dignity co-exists with the foundational ideals of a liberal democracy:

Liberalism is first and foremost about regard for the human person, about an overarching respect for individual rights and freedoms. It stands for "peace through toleration, law-bound liberty and a rightsorientated conception of justice." Respect for individual autonomy means that, for the most part, the individual occupies a "qualified position" of primacy over the collective; this in turn includes "the right to define, revise, and pursue a vision of the good life." Liberalism is equalitarian, holding that all members of society are of equal moral worth and possess the same legal and political rights. It acknowledges threats to individual autonomy inherent in the overarching quality of State authority and in the potential for an intolerant use of power by the political majority. Accordingly, it seeks to mitigate social and political relationships because it assumes that "individual rights have a substance worth preserving." It seeks to safeguard liberty.... It identifies the need for checks and balances on

Ibid. at 17 .

Ibid. at 27.

McClung J.A. relies on several quotes from members of the Supreme Court of Canada, including Mr. Justice Sopinka in Rodriquez v. B.C.(A.G.), [1993] 3 S.C.R. 519 at 589, quoted in Vriend, ibid. at 13 and Mr. Justice Major in Zeitel v. Ellsheid, [1994] 2 S.C.R. 142, quoted in Vriend, ibid. at 17. 
government and political majorities to avoid abuses of power; it affirms the principle of governmental accountability as well as the constructive possibilities of human rationality. ${ }^{35}$

The Magna Carta, the French Declaration of the Rights of Man, the American Bill of Rights, the United Nations Universal Declaration of the Rights of Man, and the Canadian Charter exemplify the conviction that there must be restraints on majoritarianism and state power in a liberal democratic society. These restraints, described by Mr. Justice McClung as a "leghold," ${ }^{36}$ are not properly so called. It is consummate with the ideals of a modern liberal democracy to assert and protect constitutionally the fundamental equality of all human beings, because of their common humanity.

It is worth recalling that judicial passivism was operative in many 19th and early to mid-20th century American judgments which upheld discriminatory state legislation. For example, passivism is recommended by Mr. Justice Brown in Plessy, an action brought exactly one hundred years before Vriend, with the result that state legislation requiring blacks to ride in separate trains cars from that of whites was ruled to be constitutional. ${ }^{37}$ In his reasons, Mr. Justice Brown noted that:

the case reduces itself to the question whether the statute of Louisiana is a reasonable regulation, and with respect to this there must necessarily be a large discretion on the part of the legislature. In determining the question of reasonableness it is at liberty to act with reference to the established usages, customs and traditions of the people, and with a view to the promotion of their comfort, and the preservation of public peace and good order. ${ }^{38}$

This sounds very much like McClung J.A.'s pronouncement that:

the Legislative Assembly of the Province of Alberta is better equipped to weigh and, if it chooses, to legislate in respect of, competing social values such as those underlying this case is not difficult to demonstrate. Put simply, the legislature has the tools annealed by centuries of constitutional, political and military conflict, tradition and pragmatism, backed by popular loyalty and confidence, to make laws of general application. ${ }^{39}$

McClung J.A. is clearly concerned that judges venture into the legislative arena too easily and therefore quotes the following warning from Harlan Fiske Stone, later the Chief Justice of the United States Supreme Court:

S. O'Byrne, "Towards an Integrated, Liberal Theory of the Canadian State" (1992) 33 C. de D. 1057 at $1084-85$, footnotes omitted. The first two quoted references are from S. Macedo, Liberal Virtues: Citizenship. Virtue and Community in Liberal Constitutionalism (Oxford: Clarendon Press, 1990) at 40, 78. The last quoted reference is from J. Blum, "Critical Legal Studies and the Rule of Law" (1990) 38 Buffalo Law Review 59 at 71. 
The courts are concerned only with the power to enact statutes, not with their wisdom.... For the removal of unwise laws from the statute books, appeal lies not to the courts but to the ballot....

While unconstitutional exercise of power by the executive and legislative branches of the government is subject to judicial restraint, the only check upon our own exercise of power is our own self-restraint.... Courts are not the only agency of government that must be assumed to have the capacity to govern."

It is worthy of note that Chief Justice Stone had a later opportunity to address this issue in concrete fashion in the 1944 decision of Steele v. L. and N.R. Company. ${ }^{41} \mathrm{Mr}$. Steele, a black man, was discriminated against by the railway union when - due to his race - it prevented him from acquiring seniority in his employment as a railway fireman. ${ }^{42}$

Steele made complaint to the court, but the Supreme Court of Alabama struck Steele's claim as disclosing no cause of action. That court found nothing in the legislation to prevent the type of discrimination suffered by Steele. The statute required the railroad to bargain with the democratically elected Union, which Union was given plenary power to draw distinctions among its membership in respect of such matters as advancement.

In response to this analysis, Stone, C.J., stated on appeal:

If, as the state court has held, the Act confers this power on the bargaining representative of a craft or class of employees without any commensurate statutory duty towards its members, constitutional questions arise. For the representative is clothed with power not unlike that of a legislature which is subject to constitutional limitations on its power to deny, restrict, destroy or discriminate against the rights of those for whom it legislates and which is also under an affirmative constitutional duty equally to protect those rights. If the Railway Labor Act purports to impose on petitioner and the other Negro members of the craft the legal duty to comply with the terms of a contract whereby the representative has discriminatorily restricted their employment for the benefit and advantage of the Brotherhood's own members, we must decide the constitutional questions which petitioner raises in his pleading. ${ }^{3}$

Chief Justice Stone also held that Congress, in enacting the empowering legislation, cannot be taken to have conferred on the Union the power to discriminate on the "irrelevant and invidious" basis of race. ${ }^{44}$ As a remedy, the Court reconstituted the federal Railway Labor Act to ensure that Steele could not be discriminated against.

Clearly, there are two possible ways of understanding the approach of the Court in Steele. Either the court "read down" the empowering legislation such that the statute did

Ibid. at 36, quoting Stone C.J. from D. Pearson \& R.S. Allen, The Nine Old Men (New York: Doubleday, Doran \& Company, Inc., 1936) at 99.

323 U.S. 192 (1944) [hereinafter Steele].

Mr. Steele was not a member of the Union but the Union was empowered by statute to act as the exclusive bargaining agent on behalf of the railroad's employees, including Mr. Steele.

Supra note 41 at 198-99 [emphasis added].

Ibid at 203. 
not confer on the Union the power to discriminate on the basis of race, or the court "read into" the legislation a non-discrimination clause. The central point becomes this: Stone C.J. had no difficulty with the general proposition that the courts are empowered with the authority and the responsibility to ensure that legislation meets the positive demands of constitutionality. Indeed, in United States v. Carolene Products ${ }^{45}$ Justice Stone suggested that the limits of judicial restraint are reached when, inter alia, the rights of minorities are infringed. That is, special judicial scrutiny - or judicial activism - is called for when minority rights are under attack. ${ }^{46}$ The Supreme Court of the United States has had recent opportunity to give such scrutiny to "Amendment 2 " to the Colorado State Constitution in Romer v. Evans. ${ }^{47}$ This Amendment repealed all ordinances, or portions thereof, which prohibited discrimination on the basis of "homosexual, lesbian or bisexual orientation, conduct, practices or relationships" ${ }^{48}$ and prohibited all legislative, executive or judicial action at any level of state or local government designed to protect the status of those of a homosexual, lesbian or bisexual orientation. ${ }^{49}$ Rejecting the argument that the amendment does no more than deny homosexuals "special rights, ${ }^{150} \mathrm{Mr}$. Justice Kennedy states:

We must conclude that Amendment 2 classifies homosexuals not to further a proper legislative end but to make them unequal to everyone else. This Colorado cannot do. A State cannot so deem a class of persons a stranger to its law."

\section{Historical Deference}

Mr. Justice McClung notes in his judgment that when the Charter was being drafted, the Parliamentary Committee advising on the matter intentionally left sexual orientation out of the list of prohibited grounds of discrimination contained in S. 15:

"sexual orientation" is not embraced by the IRPA by what must be presumed to be the preference of the Alberta electorate. The record with which we have been provided confirms that it was just that. It was propounded; it has been debated; it has been declined. By the judgment under appeal, it is only

304 U.S. 144 (1938) at 152-53n4.

See A.T. Mason, "Judicial Activism: New and Old" (1969) 55:1 Virginia L.R. 385 at 394. 1996 WL 262293 (U.S.) [hereinafter Romer].

Colorado Constitution, art. II, s. 30b, quoted by Mr. Justice Kennedy in Romer, ibid. at *2.

Ibid.

Ibid. at *3.

lbid. at *9. While there are important differences between Vriend and Romer regarding the legislative strategies at play, the outcome for the homosexual community is identical. The IRPA fails to protect homosexuals by being silent with respect to a form of discrimination that only homosexuals suffer, namely, that based on sexual orientation. Put another way, if it is only homosexuals who are fired from their jobs on the basis of sexual orientation - because employers do not object to heterosexuality - then the IRPA's silence on this point discriminates by failing to accord the homosexual community with legal protection from bigotry. Put another way still, legislative silence in the IRPA has the same intent and effect as would a positive enactment permitting discrimination on the basis of sexual orientation or - to take a page from the Colorado amendment - prohibiting protection on that basis. Regardless of which legislative avenue is chosen, the outcome is identical whether one is a lesbian living in Colorado or a gay man in Alberta: discrimination on the basis of sexual orientation is functionally not actionable. 
there [i.e.: read into the IRPA by the lower court] because it has been extracted from Charter s. 15(1), and where the term "sexual orientation" in 1995 has been judicially supplied by the Supreme Court of Canada, although emphatically rejected by Parliament's agency, the Commons Justice Committee proceedings in 1981 - proceedings struck to receive public guidance as to reach of the incoming Charter. ${ }^{32}$

This commentary is consistent with the historical deference response to judicial review alluded to earlier in this article. True to its defects, it sets up echoes of the United States Supreme Court's 1857 decision in Dred Scott, ${ }^{53}$ a case affirming the constitutionality of slavery laws based on historical deference to the framers of the United States Constitution. In short, the framers of the Constitution did not intend the protections afforded by the Constitution and the Bill of Rights to apply to blacks; hence, Scott had no standing to make complaint that his constitutional rights were violated by slavery laws. For good measure, the court also ruled that federal laws prohibiting slavery in the new territories ran afoul of the constitutional right of property in slaves.

Dred Scott is a case which McClung J. himself references in order to underscore the limited role which the judiciary ought to assume in civil rights issues. That is, he quotes Horace Greely's comment on Dred Scott that: "It makes more sense to trust a dog with my dinner than trust the Supreme Court with the slavery question!" 54 The point which McClung J.A. appears to be making is that the Courts sometimes fail to overturn evil laws, (such as slavery laws, as was the case in Dred Scott), judges being no smarter than legislators. Even so, this does not provide a rationale to exclude Courts from assessing the constitutionality of laws. Indeed, the decision in Dred Scott cuts both ways. It also stands as an admonition against excessive judicial passivity and deference.

Supra note 1 at 32 . See Romer, supra note 47 at $* 18$ where this echoes Justice Scalia's dissenting opinion in Romer regarding Colorado Amendment 2 wherein his Lordship said he would strike down the amendment as unconstitutional. In Justice Scalia's words,

Today's opinion has no foundation in American constitutional law, and barely pretends to.

The people of Colorado have adopted an entirely reasonable provision which does not even disfavour homosexuals in any substantive sense but merely denies them preferential treatment. Amendment 2 is designed to prevent piecemeal deterioration of the sexual morality favored by a majority of Coloradans, and is not only an appropriate means to that legitimate end, but a means that Americans have employed before. Striking it down is an act, not of judicial judgment, but of political will. I dissent.

While it is true that the United States Supreme Court has ruled that anti-sodomy statutes can be constitutional, it certainly has not ruled that such statutes must or should be enacted. Further, as his Lordship acknowledges, Colorado was among the first of the 25 American States which have repealed their antisodomy laws: ibid. at *13. Finally, and most importantly, it is one thing for a court to accept the right of citizens to express moral disapproval, if they must. It is quite another thing, to quote from the majority decision, to endorse an amendment "identifying persons by a single trait and then denying them the possibility of protection across the board": ibid. at *1. Supra note 6. 


\section{Conclusion}

It has been seen that Justice McClung's answer to the tension in democracy between parliamentary sovereignty and constitutional constraints is to rely, at least in part, on judicial passivism and historical deference. McClung J.A.'s answer to the dilemma also possesses the defects which Dworkin, in the chart set out in part II of this article, identifies with these responses. Passivism has the effect of ignoring as unpalatable to majoritarianism the disabling sections of the Constitution, sections which are part of the supreme law of Canada. This cannot be the proper judicial response. Historical deference has the effect of producing or validating a perspective which is - to use Dworkin's words describing the defects of historical deference - "an extremely conservative, even antiquated constitution which favors established political and economic arrangements." ${ }^{\text {"Ss }}$ The outcome in Vriend is, indeed, a decision which declines to interfere with the status quo and one which thereby refuses to recognize and protect the human rights of lesbians and gays. Mr. Justice McClung's judgment tolerates and, albeit unintentionally, condones homophobia.

Dworkin argues for integration as palliative to the tension between the notion of judicial review and the majoritarianism. That is, disabling provisions should be interpreted in a manner based on:

a communal conception of democracy ... [because it] permits us to understand disabling constitutional provisions not as compromising democracy but as an important part of the democratic story. We make the best of the legal order as a whole, subordinating neither of its central structuring features to the other, by interpreting disabling clauses as edicts of political and moral principle protecting democracy, not the residue of historical politics or embarrassments to be ignored so far as possible. ${ }^{\text {\$6 }}$

Applied to the case under review, Dworkin's analysis would be as follows. Section 15 is part of the Charter and must be invoked by the judiciary not as a last resort but with the confidence that remedying human rights violations is commensurate with the foundational principles of a liberal democratic society.

Of course, none of this is to say that the judiciary is necessarily wiser than anyone else in determining such issues. But through painstaking learning in constitutional history and theory, careful deliberations founded on an incremental, case-by-case approach to the expounding of legal doctrine, and a principled adherence to stare decisis, all of which are hallmarks of the legal decision-making process, the judiciary is certainly in good position to do so. In fact, the choice of the judiciary over government as arbitrator of human rights issues between the state and an affected

Supra note 22 at 327 . Justice McClung's approach is also contrary to Justice Mclntyre's pronouncement in Andrews v. Law Society of British Columbia, [1989] 1 S.C.R. 143 at 175 [hereinater Andrews] that s. 15 of the Charter must be interpreted in a "broad and generous manner, reflecting the fact that they are constitutional provisions not easily repealed or amended but intended to provide 'a continuing framework for the legitimate exercise of governmental power' and at the same time, for the 'unremitting protection' of equality rights." 
individual or group has the salutary effect of ensuring that a party to the dispute - the government - is not also made the judge of it. ${ }^{57}$

It is even more to the point to note that, regardless of its infirmities or reluctance, the judiciary is required by ss. 24 and 52 of the supreme law of Canada to take up the challenge of protecting human rights and enforcing the disabling provisions of the Constitution..$^{58}$

Furthermore, Mr. Justice McClung's apparent exercise in judicial self-loathing is surely less than ingenuous. His view - that courts ought to retreat from "social problems"s9 because their pronouncements, when compared to legislative ones, are difficult to change - is implausible.

First, the difficulty with which errors may be corrected offers no assistance in determining whether the courts should play a role in determining, under the Charter, the scope of human rights legislation. When a legislature makes a mistake, that too can be hard to change. For example, Alberta's eugenics legislation, the Sexual Sterilization Act, ${ }^{60}$ promulgated in 1928 , was not repealed until $1972 .{ }^{61}$

Second, judicial views do get overturned on appeal. The availability of multiple levels of appeal exists, inter alia, to protect against willy-nilly judicial misadventures, as does the doctrine of stare decisis.

Third, sometimes judges do acknowledge that earlier judgments were simply wrong. Thus, judicial pronouncements need not, contrary to his Lordship's assessment, resemble "nuclear waste" and "stay where they first settle."62

Fourth, objectionable judicial "privateering in parliamentary sea lanes, ${ }^{\text {"63 }}$ to use his Lordship's words, can be answerable to s. 33 of the Charter, the legislative over-ride. Clearly, the purpose of $s .33$ is to ensure that if the judiciary went too far in the eyes of the Legislature, the Legislature had the final say over the matter and would be guaranteed the last word. ${ }^{64}$ But contrary to the clear words of the provision, Mr. Justice McClung appears to believe that $\mathbf{s .} 33$ is no longer available to the legislature when judges choose to grant the remedy of reading in. ${ }^{65}$ If this is his view, it is

This notion has been around since at least the writings of John Locke and has been persuasively argued by Alexander Hamilton in The Federalist: see S.B. Gabin, "Judicial Review, James Bradley Thayer, and the 'Reasonable Doubt' Test" in K.L. Hall, ed., Judicial Review in American History (New York: Garland Publishing Inc., 1987) 211 at $213 \mathrm{ff}$.

See Ely's description of the judiciary as peculiarly well-situated to discharge the function of "representation-reinforcers," Ely, supra note 24 at 101-04.

Supra note 1 at 7.

S.A. 1928, c. 37.

S.A. 1972, c. 87, as recently described by Madam Justice Veit in Muir v. The Queen (25 January 1996), Edmonton 890320759.

Vriend, supra note 1 at 28.

Ibid. at 36.

P. Hogg, Constitutional Law of Canada, 3d. ed. (Toronto: Carswell, 1992) at 802-03.

Supra note 1 at 37-38. 
incorrect because the "remedied" legislation could simply be repealed and another reenacted in its original form, with an express reliance on s. 33 .

Fifth, if Justice McClung's belief took judicial hold that the best determinant of human rights issues is the legislature and not the Court, there would not be much point in having a Charter at all. ${ }^{66}$ The Charter would simply be reduced to the marginalized role of the Canadian Bill of Rights, which was all but still-born due to judicial passivism. The fact that Canada underwent a long, painful process to patriate the Constitution with an entrenched Charter of Rights of Rights and Freedoms is legally significant. It means that these rights are to be taken seriously, and that the Courts are meant to play a role in ensuring that end is met. As Dworkin notes, it is important that legal interpretation adopts a "coherent account of the legal order as a whole."167 $\mathrm{Mr}$. Justice McClung is not entitled to pick and choose amongst its components. ${ }^{68}$

\section{RECASTING THE LEGAL ISSUE AS A MORAL ONE}

A related ethos underlying Mr. Justice McClung's conception of civil rights is found in the following quotation wherein he casts Vriend's legal complaint as, in essence, a moral question:

That "sexual orientation" is so obviously a divisive issue, like right-to-life or euthanasia (issues which are also touched by the declarations of the Canadian Charter of Rights and Freedoms), does not, by its gravity alone, force the hand of the legislator. You cannot legislate morality or successfully order people to love each other. Both are battered old bromides. But as practical considerations, both survive. As Thomas Reed, long time speaker of the U.S. House of Representatives warned a century ago; "... One of the greatest delusions in the world is the hope that the evils in this world are to be cured by legislation. ${ }^{169}$

There is no need to go back to the nineteenth century for this aphorism. Speaking just before the U.S. Senate passed the Civil Rights Act of 1960, Senator Fullbright

Ely, supra note 24 at 8.

Supra note 22 at 344.

Furthermore, McClung J.A. is not entitled to reproach those members of the judiciary who do take seriously their duties under the Charter. The last sentence in the following quotation, supra note 1 at 32 , is entirely inappropriate both for the image it invokes and the criticism it makes:

Chief Justice Lamer, speaking in his capacity as Chairman of the Canadian Judicial Council, has answered extenuato, the increasing criticism of the practice of judges doubling as law makers. The Chief Justice reminded critics that this new prerogative was politically thrust upon an unwilling Canadian judiciary by the imperatives of the Charter alone. We, the judges, are said to be merely answering the politician's summons. This is no doubt so, but, disquietingly, more and more judges are lying back and enjoying it.

McClung, J.A. seems to be upset that any superior Court Judge would have the temerity to rule any piece of legislation unconstitutional as this would override "the expressed and sovereign will of the Alberta Legislature, where it had passed on a matter within its competence under the Constitution Act of Canada": supra note 1 at 23. Again, he is making an argument against having a Charter at all, a position which was debated and lost prior to the enactment of the Constitution Act, 1867.

Ibid. at 15-16. 
addressed the Senate on the matter of race relations and intoned: "legislation to regulate men's mores is doomed to failure from the day it is introduced." ${ }^{70}$

This attitude, whether judicial or legislative, manifests an egregious approach to the entire notion of civil rights, an attitude exemplified in Plessy," alluded to earlier in this article. Mr. Plessy was a black man who paid the fare to take a train trip in the state of Louisiana and was directed by the railway employees to a car designated for use by black patrons. Plessy refused to participate in this form of racial segregation and insisted on going into a coach designated for use by white patrons. He later challenged the Louisiana statute which provided for the creation of "separate but equal" facilities on the trains for white and black customers, and which also levied a penalty on those customers who refused to comply. In his reasons for upholding the statute, Mr. Justice Brown notes:

The argument [of Plessy]...assumes that social prejudices may be overcome by legislation, and that equal rights cannot be secured to the negro except by an enforced commingling of the two races.... Legislation is powerless to eradicate racial instincts or to abolish distinctions based upon physical differences, and the attempt to do so can only result in accentuating the difficulties of the present situation. ${ }^{2}$

Like Mr. Justice McClung, Mr. Justice Brown is loath to second guess the legislature and also recommends the view that the judiciary is both ill-equipped and ill-advised to counter what is regarded as public sentiment. The point is this: precisely the type of judicial reasoning employed by McClung J.A in. 1996 was used to justify and uphold the post-bellum Jim Crow laws of the United States until the decision in Brown v. Board of Education ${ }^{73}$ overturned the pernicious "separate but equal" doctrine. It is a telling and bitter irony that the lesbian and gay community in Alberta is now faced with the same arguments, on the centennial of the decision in Plessy, barring their entitlement to an equal role in society.

An antidote for such judicial recalcitrance and helplessness is found in the passage from the famous dissent of Mr. Justice Harlan in Plessy:

There is no caste here. Our Constitution is color-blind, and neither knows nor tolerates classes among citizens. In respect of civil rights, all citizens are equal before the law. The humblest is the peer of the most powerful. The law regards man as man, and takes no account of his surroundings or of his color when his civil rights as guaranteed by the supreme law of the land are involved. It is, therefore, to be regretted that this high tribunal, the final expositor of the fundamental law of the land, has reached the conclusion that it is competent for a State to regulate the enjoyment by citizens of their civil rights solely upon the basis of race. 
In my opinion, the judgment this day rendered will, in time, prove to be quite as pernicious as the decision made by this tribunal in the Dred Scott case. ${ }^{74}$

\section{EXAGGERATING VRIEND'S LEGISLATIVE EXPECTATIONS}

On a related front, McClung J.A. endeavours to discredit Mr. Vriend's claim by exaggerating both that which Mr. Vriend seeks and the disabilities of the legislature in dealing with discrimination, by stating: "You cannot legislate morality or successfully order people to love each other." 75

It is patent that Mr. Vriend is not seeking to legislate morality or have anyone ordered to love anyone. He would like a chance to complain to the Alberta Human Rights Commission that he was fired from his position as a laboratory co-ordinator because, and only because, he is homosexual. It is, with respect, implausible to imply, as his Lordship does, that providing for this modest constitutional entitlement is beyond the capabilities of the Legislature.

\section{E. RECOMMENDING THE ALBERTA GOVERNMENT'S "COMPROMISE" POSITION REGARDING LESBIAN AND GAY RIGHTS}

\section{Stepping Back From the "Social Issue"}

McClung J.A. notes the apparent savvy of some Canadian political figures in choosing to address social issues with reluctance, if at all. ${ }^{76} \mathrm{He}$ also asserts that the silence of the IRPA regarding sexual orientation is both a compromise and has the salutary effect of leaving the matter of the treatment of homosexuals to private resolution. McClung J.A. even suggests that, through such an approach, the Alberta Legislature has steered a middle course between, as his Lordship describes it, the "platforms of the divinely-driven right and the rights-euphoric, cost-scoffing left." It is not obvious to the writers how the Alberta Legislature has chosen a path between the political right and the political left in leaving "sexual orientation" out of the IRPA. The "right," one assumes, wants "sexual orientation" out of the IRPA and it is out. The "left," one also assumes, wants protection for homosexuals in the IRPA - but it is still out. In fact, the Alberta legislature has functionally gone as far as it can to further the agenda of the "divinely-driven right." Even if it were possible, the IRPA evidences no wisdom-driven middle path and no compromise.

Furthermore, to leave the human rights of Alberta's homosexual community to be determined by the marketplace is not only a regression to the reasoning in Dred Scott but it validates the homophobic attitudes of individuals such as Reform Party Member of Parliament, Bob Ringma, who stated to a Vancouver newspaper on April 29, 1996 
that he would dismiss "or move to the back of the shop" any gay or black employees whose presence offended customers:

If I had a business and a homosexual was there working for me and he was responsible for my losing business, then indeed I would think of letting him go, just as I would think of letting go anyone else who was losing business for me. ${ }^{7 n}$

So that this kind of commentary is not taken as anomalous, the writers also reference a comment recently made Dr. Grant Hill, another federally elected member of the Reform Party, regarding the Government of Canada's Bill to introduce sexual orientation as a prohibited ground of discrimination under the Canada Human Rights Act. Hill, a medical doctor, stated during debate on Bill C-33 that if homosexuals were protected from discrimination, it would encourage the spread of disease and promote an unhealthy lifestyle:

My specific problem with this bill is that it will produce and allow a promotion of an unhealthy lifestyle, [because homosexuals suffer from] HIV, gay bowel syndrome, increasing parasitic infections, lowered life expectancy and...hepatitis."

Hill also stated that he does not believe the bill is a question of human rights: "These things have been treated as a human rights issue instead of as a medical issue and as a physician I don't think that's smart."180

Members of the Liberal party have also echoed these kind of sentiments. Ontario Liberal MP Albina Guarnieri has compared the amendment to "a Trojan horse whose hidden payload was filled with legal ammunition for the war against traditional family values. ${ }^{"{ }^{81}}$ Toronto Liberal MP Tom Wappel opposes the amendment because it would promote unhealthy sexual behaviour, ${ }^{82}$ because: "The vast majority of homosexual liaisons are of a promiscuous nature....This, just like promiscuity in heterosexuals, is unhealthy." ${ }^{183}$

Such commentary from Canada's elected officials adds poignancy to the words of Madam Justice Russell, quoted earlier, and make them worth repeating at this juncture:

J. Morris, "Party backs Reform MP who would fire blacks, gays" National General News (30 April 1996) CP No. 96 (QL). L. Drouin, "Reform MP says equality for gays would promote unhealthy lifestyle" National General News (7 May 1996) CP No. 96 (QL).

(⿻) Ibid. This comment was made outside the House. It should atso be noted that the leader of the Reform Party, P. Manning, has, belatedly, condemned these remarks.

81 N. Ovenden, "Liberal dissenters unscathed by controversy" The Edmonton Journal (16 March 1996).

$\times 2$ Ibid.

* Ibid. Wappel's bizarre assessment of the Bill underscores the accuracy of Cory J.'s comment in Egan that one stereotype rcgarding homosexuals is that they do not form "lasting relationships." 
[T]he effect of the [Government of Alberta's] decision to deny homosexuals recognition under the legislation is to reinforce negative stereotyping and prejudice thereby perpetuating and implicitly condoning its occurrence. ${ }^{\mathrm{ks}}$

In The Dynamics of Sexual Orientation and Adolescent Suicide; $A$ Comprehensive Review and Developmental Perspective, ${ }^{85}$ Ian T. Kroll, M.D. and Lorne B. Warneke, M.D. point directly to the failure of the government to protect homosexuals in human rights legislation as having a significant contributing deleterious effect on homosexual adolescents and their response to a society which has "stepped back" from them namely, suicide. It is chillingly documented by the authors that Canada has the highest rate of adolescent suicide in the Western world and Alberta has the highest rate among the provinces in Canada. More specifically for the purposes of this article, the study establishes that the rate of suicide for homosexual adolescents is two to three times that of heterosexuals. As stated by the authors:

\begin{abstract}
Knowing the consequences of the social, emotional and cognitive isolation and despair of these youth makes it more understandable why Alberta, one of the last provinces in Canada to include sexual orientation as part of human rights protection, also has one of the highest youth suicide rates in the world. Tragically, governments, perhaps because of individual politicians' own fears and misconceptions of homosexuality or fear of political "guilt by association," have not taken on the responsibility of ensuring the protection, safety and well-being of those of our children who happen to have a same-sex orientation. Government legislation would seem a logical step in affirming the inherent value of all citizens, giving such youth a "place" in our future and providing them the same opportunities, privileges, safety, rights and responsibilitics as any other Canadian. Instead, the suffering these youth are subject to daily is continuously reaffirmed. ${ }^{x_{1}}$
\end{abstract}

Indeed, the situation faced by Mr. Vriend - being fired for his sexual orientation speaks with blunt eloquence to the manner in which the IRPA exacerbates and validates the lot of Alberta's gay and lesbian community by failing to give them a legal voice.

Mr. Justice McClung again endorses the marketplace solution when he suggests that there is nothing wrong when the Alberta legislature decides to "step back from the validation of homosexual relations, including sodomy, as a protected and fundamental right, thereby [not] '...rebutting a millennia of moral teaching. "'87 Yet, if the validation of homosexual relations comes at the expense of reversing millennia of moral teaching, one's response ought to be a deep moral anger - not that it is being done, but that it took so long. The practice of slavery also had a long and distinguished moral basis in western culture, at least until the 19th century. The pedigree of the prejudice is no justification for bigotry.

Vriend (Q.B.), supra note 12 at 431.

Drs. I.T. Kroll \& L.B. Warneke, The Dynamics of Sexual Orientation and Adolescent Suicide; $A$ Comprehensive Review and Developmental Perspective (University of Calgary and University of Alberta, 1995).

Ibid. at 42 , references deleted.

Supra note I at 19. 
Furthermore, why is Mr. Justice McClung referring to sodomy at all? Mr. Vriend was not fired because he was found engaging in sodomy or any other sexual activity at work - he was fired for being a homosexual. He lost his job because the imaginations of his employers were distasteful to the imaginers.

\section{Legislation and What Counts as Government Action}

Not only is McClung J.A.'s agreement with the marketplace solution to human rights contrary to liberal political theory, which holds that human rights are not matters to be abandoned to majoritarianism, it is contrary to existing case law. There is considerable authority for the proposition that while the Charter cannot compel the government to legislate, legislative silences can nonetheless attract Charter scrutiny depending on the circumstances and legal test used. Accordingly, Mr. Justice McClung's minority position regarding the omission of sexual orientation from the IRPA, - that "[w]hen they choose silence provincial legislatures need not march to the Charter drum" ${ }^{88}$ is impeachable.

It should be noted that the legal significance of under-inclusive legislation can be dealt with as a threshold matter under s. 32 , as a s. 15 matter, ${ }^{89}$ or as both. That is, one can ask whether the legislative silence counts as government action, on the one hand, or one can ask whether the legislative silence amounts to drawing a distinction on a ground prohibited by s. 15, on the other. Given that analysis in Vriend covers largely the same kind of terrain, judicial commentary under both sections will be dealt with in this part of the article.

Mr. Justice McClung deals with the legislative silence question as a s. 32 matter and finds there to be no government action. This is in contrast to the views of Madam Justice Hunt who plainly states, in dissent in Vriend, that it is not private activity which is being impugned. Rather, the complaint regards a provincial law and "more generally, the actions of the Legislature in refusing to extend the IRPA to homosexuals.... This is enough to engage the Charter."${ }^{190}$ Similarly, while Mr. Justice O'Leary in Vriend found no Charter breach, he does acknowledge that the IRPA is subject to Charter scrutiny because:

I recognize that in some circumstances a statute may infringe s. 15(1) by what it fails to say: see for example Miron v. Trudel (1995), 181 N.R. 253 (S.C.C.), in which it was held that the Ontario Insurance Act, R.S.O. 1980, c. 218 , violated s. 15(1) by providing accident benefits only to legally married spouses and not to common-law spouses."

Ibid. at 12.

See Hunt J.A.'s statement, Vriend, supra note 1 at 19-20, that the legislative omission "could also be considered to arise in the context of $s .32$... [b] ut for reasons, already given, 1 ... prefer to treat the issue as a s. 15(1) question...." See also D. Pothier, "Charter Challenges to Underinclusive Legislation: The Complexities of Sins of Omission" (1993) 19 Queen's L.J. 261 at 278.

Vriend, ibid. at 4.

lbid. at 2. 
Mr. Justice Barry in Re Nolan and the Queen, ${ }^{92}$ a case analogous to Vriend, makes a very similar observation regarding the applicability of the Charter $^{93}$ as does $P$. Hogg. 94

It should be noted that McClung J.'s analysis - that there is no government action - is largely in accord with O'Leary's s. 15 analysis that the IRPA is merely neutral and in no way draws "any distinction between the protection it affords to individuals on the basis of sexual orientation. Failing this, it cannot infringe s. 15(1) of the Charter on this basis." 95 The starting point for rebuttal of this kind of reasoning is the Supreme Court of Canada's analysis in Egan v. Canada ${ }^{96}$ in which the unanimous court recognized that homosexuals have suffered an historic disadvantage and are entitled to s. 15 protection under the analogous ground category. Cory J., for himself and Iacobucci J., in Egan, acknowledges that such a disadvantage:

has been widely recognized and documented. Public harassment and verbal abuse of homosexual individuals is not uncommon. Homosexual women and men have been the victims of crimes of violence directed at them specifically because of their sexual orientation.... They have been discriminated against in their employment and their access to services. They have been excluded from some aspects of public life solely because of their sexual orientation.... The stigmatization of homosexual persons and the hatred which some of the public have expressed towards them has forced many homosexuals to conceal their orientation. This imposes its own associated costs in the workplace, the community and in private life. ${ }^{n}$

Egan, as a pronouncement from the highest court of the land cannot be shrugged off, as McClung, J.A. attempts to do in the following passage:

Simply stated, and notwithstanding Egan v. Canada, supra, the omission of the phrase "sexual orientation" by the elected law-makers of this province as one of the declared discrimination commandments of the IRPA, does not amount to governmental action for the purpose of s. 32(1) of the Charter."

(1995), 127 D.L.R. (4th) 694 (Nfld. S.C.T.D.) [hereinafter Nolan].

See ibid. at 715 where the Court states:

The ... [provincial] legislature adopted the Charter in 1982. It must, therefore, be taken to have approved the role given the courts by the Charter to ensure that provincial legislation conforms with the Charter and does not discriminate on grounds expressly prohibited by $\mathbf{s}$. 15(1) of the Charter or analogous grounds.

See Hogg, supra note 64 at 850 where he states:

The effect of the governmental action restriction is that there is a private realm in which people are not obliged to subscribe to "state" values, and into which constitutional norms do not intrude. The boundaries of that realm are marked, not by an a priori definition of what is "private", but by the absence of statutory or other governmental intervention [emphasis added].

Supra note 1 at 13 .

(1995), 124 D.L.R. (4th) 609 [hereinafter Egan].

lbid. at 674. As Mr. Justice Barry notes in Nolan, both L'Heureux-Dube J. and McLachlin J. stated that they were substantially in agreement with the reasons of Cory J., as was Mr. Justice Sopinka with respect to the s. 15 analysis. This means that Cory J. is almost certainly the majority on this point.

Supra note 1 at 6. 
Second, the Supreme Court of Canada in Brooks v. Canada Safeway ${ }^{99}$ has already recognized, in the words of Chief Justice Dickson, for the unanimous court, that: "Underinclusion may be simply a backhanded way of permitting discrimination." 100 To this very real and important extent, legislative silence in the IRPA is government action and further it has both the intent and effect of drawing an unconstitutional distinction. As Madam Justice Hunt, in her dissenting opinion in Vriend, notes:

This case presents an issue that has not yet been decided by the Supreme Court of Canada. The special problem is this. The Alberta Legislature has passed a law, the IRPA, that offers protection from discrimination to certain groups that have been the victims of discrimination. It does not offer the same protection to another group (homosexuals) that - as the evidence here establishes - have also been the victims of discrimination.

Does the failure of the Legislature to include homosexuals as a protected group amount to the drawing of a distinction between that group and other victims of discrimination who have been afforded the protection of the IRPA? To put the matter another way, can legislative silence or omission amount to the drawing of a distinction? ${ }^{101}$

Upon an examination of the legislative context and intent in leaving sexual orientation out of the IRPA, Hunt, J.A. answered these questions in the affirmative.

Other courts - commensurate with the Supreme Court of Canada's s. 15 analysis in Egan - have recognized that a governmental failure to extend protection to gays and lesbians is discriminatory and hence subject to Charter review. For example, the Ontario Court of Appeal in Haig v. The Queen, ${ }^{102}$ a decision pre-dating Egan, ruled that the omission of sexual orientation from the Canada Human Rights Act violated s. 15. Mr. Justice Krever states:

The social context which must be considered includes the pain and humiliation undergone by homosexuals by reason of prejudice towards them. It also includes the enlightened evolution of human rights social and legislative policy in Canada, since the end of the Second World War, both provincially and federally. The failure to provide an avenue for redress for prejudicial treatment of homosexual members of society, and the possible inference from the omission that such treatment is acceptable, create the effect of discrimination offending s. $15(1)$ of the Charter. ${ }^{103}$

Additionally, the Newfoundland Supreme Court, in Nolan, a post-Egan decision, has determined that the failure of the provincial human rights code to include sexual orientation as a prohibited grounds of discrimination counts as government action and contravenes s. 15 of the Charter. Mr. Justice Barry also ruled, on the basis of expert evidence, that "homosexuals are a disadvantaged group who suffer further disadvantage 
when they fail to receive needed protection which has been granted to others." ${ }^{104}$ The court also noted that the exclusion of homosexuals from the protection of the Newfoundland Human Rights Code "undermines the worthy objectives of the legislature by implicitly condoning attacks upon the human dignity of homosexuals." 105

Echoing this kind of analysis, Russell J. for the Queen's Bench and, Hunt J.A., in dissent for the Court of Appeal, ruled properly on the point. Hunt J.A., for example, determines:

From this legislative history, I think it is plain that the discrimination suffered by homosexuals in society in general and in the work place in particular has been clearly drawn to the attention of the Legislature. The existence of that discrimination further suggests to me that there is, in some sectors of Alberta society, a hostility toward homosexuals for reasons that have nothing to do with their individual characteristics as human beings, and everything to do with presumed characteristics ascribed to them by those members of society based only upon their membership in a group that has suffered historical disadvantage. Given this context and these facts, the purpose of the Legislature's refusal to act in this situation is to reinforce stereotypical attitudes about homosexuals and their individual worth and dignity. ${ }^{106}$

While the Supreme Court of Canada has not yet ruled on whether a provincial human rights act governing the private sector must include all the enumerated and analogous grounds of discrimination under s. 15 - and Madam Justice L'Heureux-Dube' has in fact said in obiter that this is not required ${ }^{107}$ - there is also judicial analysis to the effect that once the legislature has begun to impose human rights limitations on market activity, it must meet Charter standards. In McKinney v. University of Guelph, ${ }^{108} \mathrm{Mr}$. Justice La Forest, for the majority, confirmed that the central object of the Charter is "essentially an instrument for checking the powers of government over the individual." 109 However, he also noted that the Charter applies to the "law":

Supra note 92 at 713.

Ibid. at 715 .

Supra note 1 at 28 . While the majority in Haig focused on the effect of the legislative omission in question, and Hunt J.A. in Vriend focuses on the legislative purpose, the approaches are not, it is suggested, mutually exclusive and can be combined, as will be argued below.

See McKinney v. University of Guelph, [1990] 3 S.C.R. 229 at 436 [hereinafter McKinney]. L'Heureux-Dubé, J. says in dissent: "If the provinces chose to enact human rights legislation which only prohibited discrimination on the basis of sex, and not age, this legislation could not be held to violate the Charter." Madam Justice Wilson declined to rule on such a matter since the court was not dealing with a situation in which the state had failed to act at all, ibid. at 412-413. She does state however that "I do, however, consider it axiomatic that once government decides to provide protection it must do so in a non-discriminatory manner," ibid. at 413 . It should be noted that Mr. Justice McClung in Vriend, supra note 1 at 10 quotes Madam Justice L'Heureux-Dube's dissenting opinion and then indicates that stare decisis applies in respect of this passage and that the Alberta Court of Appeal and Court of Queen's Bench are bound thereby. It would be one thing for the Court to have simply indicated that the reasoning in the quoted passage was compelling, and then to have adopted the same. It is quite another to cite obiter dicta passages from dissenting judgments as binding authority.

lbid.

Ibid. at 261. 
For s. 15 of the Charter to come into operation, the alleged inequality must be one made by "law." The most obvious form of law for this purpose is, of course, a statute or regulation.... It seems obvious from what McIntyre J. had to say in the Dolphin Delivery case that he intended that exercise by government of a statutory power or discretion would, if exercised in a discriminatory manner prohibited by $s .15$, constitute an infringement of that provision. ${ }^{110}$

And later, his Lordship states with respect to the Ontario equivalent to the IRPA: "There is no question that, the Code being a law, the Charter applies to it"111 and that differential treatment within it "constitutes discrimination for the purposes of $\mathbf{s}$. $15(1) .1112$

It must be noted that the legislative context in McKinney ${ }^{113}$ is different than in the case at bar: the Ontario Human Rights Code, rather than being silent with respect to a category of discrimination, namely age, purported to prohibit discrimination on the basis of age and then define "age" selectively so as to include only those over the age of 18 and under the age of 65 . Nonetheless, McKinney has direct precedential value for Vriend either on the broader, entirely supportable basis that once the Legislature takes the step of enacting human rights legislation, it is caught by s. 32 and must comply with s. 15 of the Charter ${ }^{114}$ or on a more narrow, incremental reading of McKinney, which includes the analysis of Madam Justice L'Heureux-Dube' regarding human rights legislation, and is aligned with the Supreme Court of Canada's s. 15 analysis in, inter alia, Egan, ${ }^{115}$ Brooks, ${ }^{116}$ and Symes v. Canada. ${ }^{117}$ The narrower analysis would be that "silence" by the legislature will amount to government action - and the drawing of a distinction within the meaning of s. 15 - at least when:

a) there is legislation regarding one or more groups identified under s. 15 as enumerated or analogous which legislation also does not include or extend to another historically disadvantaged group; and

Ibid at 276.

Ibid. at 290.

Ibid.

See supra note 107.

On this analysis, the Vriend case is analogous to Re Blainey and Ontario Hockey Association (1986), 54 O.R. (2d) 513 (Ont. C.A.) [hereinafter Blainey], leave to appeal refused [1986] S.C.R. vii. In Blainey, a 12 year old girl had been refused permission to play on a boy's hockey team, an exclusion which was expressly permitted by s. 19 of the then Human Rights Code. The Ontario Court of Appeal found that this provision denied Blainey equal protection and equal benefit of the law by reason of sex and so was contrary to s. 15 , ibid. at 735 . It is relevant to note that as in McKinney, the legislation in question purported to prohibit a ground of discrimination - namely sex - and then went on to limit that protection. By extension, in Vriend, it would have to be argued that when a legislature decides to provide human rights protection in the marketplace, it simply cannot pici and choose amongst disadvantaged groups, because to do so is inherently repugnant and contrary to s. 15 of the Charter. It should be noted that Madam Justice Hunt, supra note 1 at 14, and Mr. Justice O'Leary, ibid. at 6-7, did not find Blainey to be on point. Madam Justice Russell, on the other hand, followed Blainey on the grounds that sexual orientation had to be included in the IRPA because gender was: Vriend (Q.B.), supra note 12 at 430.

Supra note 96.

Supra note 99.

(1993), 110 D.L.R. (4th) 470 (S.C.C.) [hereinafter Symes]. 
b) the intent or effect (or both) of leaving out or not extending protection to that latter group is, in a "backhanded" way (to use the words of the Supreme Court of Canada in Brooks), to condone or appear to condone hatred, bigotry, or other abuse visited upon its membership.

That is, if the intent of a legislative silence in such a context is to condone abuse of a s. 15 group, then the legislative silence draws a distinction and is impeachable, regardless of whether it is effective in accomplishing this goal or not. The reason for this outcome is straightforward: such government silence is repugnant by definition and whether the plan achieves fruition or not has to be irrelevant. If the legislative silence in a human rights context has the effect of condoning abuse, it should count as drawing a s. 15 distinction because, regardless of intent, it has the appearance of State condonation of the abuse. When the legislative silence has both the intent and effect of condonation, it is impeachable for both the reasons given above. Furthermore, such condonation by the government would almost certainly amount to drawing a distinction resulting in disadvantage, thereby running afoul of the s. 15 test applied in Andrews v. Law Society of British Columbia. ${ }^{118}$ At this point, and assuming that Andrews states the law concerning the s. 15 test, the court would move to a s. 1 analysis. It is beyond the scope of this article to discuss the uncertain state of s. 15 analysis arising in particular as a result of Miron v. Trudel ${ }^{119}$ as this matter has already been thoroughly canvassed by Leon Trakman in "Section 15: Equality? Where?" 120

The approach proposed here means that not every legislative omission counts as a governmental distinction within the meaning of s. 15 . It thereby accommodates the concern which appeared, quite rightly, to motivate Madam Justice L'Heureux-Dubé's analysis in McKinney, namely that the Charter should not be used to "interfere with a legitimate provincial legislative decision not to provide rights in a given area."121 In the writers' view, her Ladyship's dissenting, obiter determination that a legislative decision to prohibit discrimination on the basis of sex and not of age would not violate

118 [1989] I S.C.R. 143 [hereinafter Andrews].

119 In Miron v. Trudel, [1995] 2 S.C.R. 418 at 435-36, Gonthier J. (in dissent) states:

The analysis to be undertaken under section 15(1) of the Charter involves three steps. The first step looks to whether the law has drawn a distinction between the claimant and others. The second step then questions whether the distinction results in disadvantage, and examines whether the impugned law imposes a burden, obligation or disadvantage on a group of persons to which the claimant belongs which is not imposed on others, or does not provide them with a benefit which it grants others, Andrews, ibid. It is at this second step that the direct or indirect effect of the legislation is examined.

The third step assesses whether the distinction is based on an irrelevant personal characteristic.... This third step thus comprises two aspects: determining the personal characteristic shared by a group and then assessing its relevancy having regard to the functional values underlying the legislation.

121 McKinney, supra note 107 at 436 [emphasis added]. It may also be the case, as noted by Hunt J.A., that "Justice L'Heureux-Dube's obiter comments in McKinney have been effectively overtaken by her concurrence in the judgment of Wilson, J. in Lavigne v. Ontario Public Service Employees Union, [1991] 2 S.C.R. 211." See D. Pothier's very well reasoned article "Charter Challenges to Underinclusive Legislation: The Complexities of Sins of Omission," supra note 89 at 281 . 
the Charter must be read subject to her own caveat which requires legitimacy in the legislative decision taken.

Further, it acknowledges the fact that, in its entire context, a distinction made among disadvantaged groups may not be related to disadvantage and should therefore not be impeachable. ${ }^{122}$ As Hunt J. notes:

there may be situations where distinctions made on enumerated or analogous grounds are nondiscriminatory, for example, where the distinction does not engage the purpose of s. 15(1), which purpose as stated in Miron ...is "to prevent the violation of human dignity and freedom by imposing limitations, disadvantages or burdens through the stereotypical application of presumed group characteristics rather than on the basis of individual merit, capacity, or circumstance. ${ }^{\mathrm{n} 123}$

Her Ladyship goes on to note that in assessing government inaction under s. 15, "[t]he most important factors are the context of the impugned legislation and whether the purpose of the Legislature in failing to act is to encourage or support the distinction that results between groups that are protected...." 124 But for reasons given earlier, the writers would go even further and claim that if the result of the legislative inaction quite apart from its intent - amounts to appearance of giving encouragement or support of human rights violations endured by the historically disadvantaged groups, it is amenable to Charter scrutiny. ${ }^{125}$

As noted by Professor Annalise Acorn, Faculty of Law, University of Alberta, in a conversation regarding this section of the article.

Vriend, supra note 1 at 8-9. She is referring to Miron v. Trudel, supra note 119.

Vriend, ibid. at 17.

The foregoing does not contradict the analysis in Adler v. Ontario (1994), 19 O.R. 3d (Ont. C.A.), leave to appeal allowed, S.C.C. bulletin 3 February 1995 [hereinafter Adler], which, contrary to Justice O'Leary's assessment in Vriend, is simply not on point. In Adler, complaint was made against the Education Act because, inter alia, it provided no public funding to children who attended independent, religious-based schools and hence allegedly contravened freedom of religion under $\mathbf{s .} 2$ of the Charter. In response, the court ruled:

In this case... there is no government action that compelled the appellants to send their children to private, religious based schools. They were free to send their children to secular public schools maintained at public expense. Their decision not to do so was solely a response to their religious beliefs and not a result of any government action: ibid. at 18 . Indeed, legislative silence in Adler did not in any way condone or encourage violation of one's freedom of religion and so could not be impugned under the proposed test. Similarly, Eldridge v. British Columbia (1995), 125 D.L.R. (4th) 323, is not on point. There it was argued that the failure to provide for medical interpreting services for the deaf under the Hospital Insurance Act was a violation of s. 15 of the Charter. While the majority agreed that $s$. 15(1) may be triggered when the effect of the legislation is to create a discriminatory distinction, there was no such distinction here because:

In the absence of the legislation, those deaf people requiring translators would be required to pay their doctors in addition to translators ... hearing people ... would be in the similar position of having the responsibility of making payment to their doctors. The legislation removes the responsibility of both the hearing and the deaf to make payment to their doctors ... the effect of the legislation is that the deaf remain responsible for the payment of translators in order to receive equivalent medical services as those with hearing, as they would be in the absence of the legislation. This inequality exists independently of the legislation and cannot be said in any way to be an effect of the legislation: ibid. at 339. 
Third, the proposed test absorbs Madam Justice Wilson's very useful analysis in Lavigne v. Ontario Public Service Employees Union ${ }^{126}$ that while some kinds of permissive legislation are not subject to a Charter challenge because they do not "connote governmental approval of what is permitted but connotes at most governmental acquiescence in it," ${ }^{127}$ this is not always true. As she notes, some kinds of permissive legislation, when considered within the context of all the circumstances of the case, move beyond acquiescence and into the realm of "governmental approval or encouragement of a particular activity" and so should be amenable to Charter scrutiny. ${ }^{128}$

In sum, the narrow test provides that, to determine whether a legislative silence counts as drawing a distinction, the court must first assess whether the legislation extends to one s. 15 group and not to another historically disadvantaged group. If the answer is yes, it must then weigh that silence in its socio-political and legal context in the manner advanced by the Supreme Court of Canada in Andrews. ${ }^{129}$ If the silence - whether intentionally or not - functions in fact or appearance to condone or "extend government approval or encouragement" with respect to attacks on the human dignity of that $s .15$ group which has not been included, it is impeachable government action because a distinction has been drawn. As Kenneth Karst in Law's Promise, Law's Expression states, social stigma is created through legal expression. ${ }^{130}$ Stigma, especially propagated by government, produces harms to the targeted groups that are both immediate and consequential. The immediate harms, he notes, are psychic: "insult, humiliation, indignity for the people stigmatized."131 But the consequential damages include, through the law's expressive qualities, a "permission-to-hate" because it legitimizes homophobia. ${ }^{132}$ The point is not that this legitimizing message will necessarily be persuasive to a majority of citizens but that the legislature offers reinforcement to the worst inclinations of those citizens "just waiting to be convinced." ${ }^{133}$ In accord with Karst's analysis, strategic legislative silences cannot be ignored by the court.

Supra note 121.

Ibid. at 247.

Ibid. at 248. Pothier, supra note 89 at 282 , persuasively identifies Wilson J. as providing the key to dealing with the permissive legislation under s. 32 and 15. She relies on Wilson J's analysis to support her conclusion that:

Where there is a well-documented history of discrimination against lesbians and gays comparable to the kind of discrimination based on the actual prohibited grounds in...the Canadian Human Rights Act, the failure to include sexual orientation as a ground does effectively amount to government approval of discrimination on the grounds of sexual orientation.

Supra note 55.

K. Karst, Law's Promise, Law's Expression (New Haven: Yale University Press, 1993) at 185-86.

Ibid.

Ibid. at 186.

lbid. 


\section{F. THE ABSENCE OF EVIDENCE}

McClung J.A. notes - in support of the government's decision to leave the matter of human rights to the marketplace - that there was no evidence before the trial judge that the government's "exercise of private choice" was discriminatory. ${ }^{134}$ Indeed, there was little proof (one has in mind expert testimony, or sociological or psychological evidence along the lines of the Brandeis brief) before Russell J. of the discrimination faced by homosexuals or of the deleterious effects on Alberta's homosexual community caused by the failure of the legislature to include "sexual orientation" as a prohibited ground of discrimination in the IRPA.

Mr. Justice O'Leary, in his concurring Reasons for Judgment for the Court of Appeal, concludes that the IRPA, in failing to proscribe discrimination on the basis of "sexual orientation" did not have any deleterious effect on the homosexual community. ${ }^{135}$ However, it must be noted that neither Mr. Justice O'Leary nor Madam Justice Hunt (although arriving at opposite conclusions) appeared to have any evidential difficulty in coming to their respective determinations on this point. ${ }^{136}$ To that extent, the findings of McClung, J.A. on this point are in the minority.

Further, McClung, J.'s conclusion on the need for evidence is in error for two reasons: first, there was material founding judicial notice before the court, ${ }^{137}$ second, it has been unanimously determined by the Supreme Court of Canada that homosexuals have suffered an "historic disadvantage," a disadvantage, in the words of two of the judges "widely recognized and documented." ${ }^{138}$ Cory J., for himself and lacobucci J. notes that homosexuals are subjected to public harassment and verbal abuse as well as suffering discrimination in employment and access to services. This certainly provides a strong foundation - if not complete support for the conclusion - that human rights legislation which fails to protect the homosexual community from such outrageous conduct condones and contributes to their second-class status in Canadian society. It is not unreasonable to infer, on the basis of analysis provided by Canada's highest

Supra note 1 at 8.

Ibid. at 13. As R. Wintemute shows in "Discrimination Against Same-Sex Couples" (1995) 74 Can. Bar Rev. 682 at 691-92 and in "Sexual Orientation Discrimination as Sex Discrimination" (1994) 39 McGill L.J. 428 at 455 and following, Mr. Justice Mclntyre' s. 15 analysis in Andrews requires that, in addition to a distinction (denying equality on one of the four grounds recited in s. 15) which is based on an enumerated or analogous ground, the plaintiff must show that the legislative impact of the law is discriminatory. See Wintemute, ibid. for discussion as to how this third requirement has been subsequently formulated by the Supreme Court Justices.

Given all the circumstances, Hunt J.A. found that the government failure to protect homosexuals in the IRPA is "tantamount to approving ongoing discrimination against homosexuals," Vriend, ibid. at 27. O'Leary, J. concluded that the IRPA's silence "does not discriminate on the basis of sexual orientation," ibid. at 8.

Madam Justice Hunt, in fact, found that there was evidence before the court showing discrimination in employment, and she appeared to accept Russell J.'s conclusion that "the discrimination homosexuals suffer is so notorious," that she could take judicial notice of it, ibid. at 27. As well, there were several studies before the court as listed in the Respondent's Factum at $14-15$.

Egan, supra note 96 at 647 
court, that a governmental failure to protect a group from human rights violations is to condone those violations.

A related point is that several courts - in accord with Egan - have reasoned that governmental failure to protect homosexuals, a group targeted for hatred and abuse, is contrary to s. 15. It is always legitimate for a judge to attach persuasive significance to the decisions of other courts.

As discussed earlier, both the courts in Haig and in Nolan (a decision not considered in Vriend) found a Charter violation in the failure of the government to include sexual orientation in its human rights legislation. ${ }^{139}$ Mr. Justice Krever in Haig, for example, noted that the legislative failure to protect homosexual members of society from discrimination and "the possible inference from the omission that such treatment is acceptable"140 creates the effect of discrimination contrary to s. 15(1) of the Charter. Mr. Justice Barry for the Newfoundland Supreme Court in Nolan, accepted affidavit evidence that gays and lesbians have "historically suffered discrimination and apart altogether from any legislative discrimination, continue to experience significant forms of discrimination today"141 and further, that the expert evidence had convinced him that "homosexuals are a disadvantaged group who suffer further disadvantage when they fail to receive needed protection which has been granted to others." ${ }^{142}$ The court also noted that the exclusion of homosexuals from the protection of the Newfoundland Human Rights Code implicitly condoned "attacks upon the human dignity of homosexuals." ${ }^{143} \mathrm{Mr}$. Justice Barry felt fortified in this assessment because, as noted earlier, "the majority of the Supreme Court in Egan recognized that homosexuals need protection from discrimination." ${ }^{144}$ Mr. Justice Barry noted his willingness to have taken judicial notice of this need for protection, had that been necessary. ${ }^{145}$

It must be said that while McClung J.A. acknowledges Egan, he simultaneously appears to criticize Madam Justice Russell for ruling in a manner which is consistent with it. He states:

I express no view on Russell J. taking judicial notice, in the absence of evidence, of discrimination and on her findings that members of the homosexual community, whether strident or stolid, have, for the purpose of the Charter s. 15(1), traditionally been and currently are discriminated against. That issue, one extensively argued before us, has been overtaken, at least in law, by the intervening judgments of the Supreme Court of Canada in [Egan]. ${ }^{146}$

This is having it both ways. If the issue is settled by the Supreme Court of Canada in Egan, there is absolutely no call to make a backhanded criticism of the trial judge.

See Haig, supra note 16 and Nolan, supra note 92.

Haig, ibid. at 10.

Supra note 92 at 698.

Ibid. at 713 .

lbid. at 715 .

Ibid. at 713.

Ibid.

Supra note 1 at $21-22$. It should be noted that Egan postdated Russell J.'s judgment. 
On a related front, it is worth noting that McClung J.A. dismisses out of hand the argument that unless the IRPA were to bar discrimination based on sexual orientation, homosexuals could be fired from their jobs (or, one supposes, lose their apartments) without cause or recourse. He states:

This in terrorem argument should not only be addressed but buried. All contracts, including contracts of employment or rental accommodation, can only be lawfully terminated before their completion for violation of their fundamental terms, proven or implied. There may be cases where the heterosexuality of one of the parties is essential to a contract's fulfilment but they would be rare and such a provision, to qualify as a fundamental term, would have to be known to the partics from the outset. ${ }^{147}$

There are three comments to be made in response to this. First, the analysis misses the point entirely. The right not to be discriminated against based on an irrelevant personal characteristic is at the heart of human rights legislation and the Charter. As Mr. Justice Barry notes in Nolan:

\begin{abstract}
Looking at homosexuals as a group, the Supreme Court in Egan has accepted they have suffered discrimination arising from stereotyping, historical disadvantage and vulnerability to political and social prejudice. As human beings they are entitled to have their human dignity preserved. They are entitled to protection from this discrimination, which could properly be described, in the words of Mclntyre J. in Andrews, at p. 18, in referring to the enumerated grounds, as among "the most common and probably the most socially destructive and historically practised bases of discrimination." $14 \times$
\end{abstract}

Second, common law remedies can only remedy a breach of contract that is in existence; they provide no recourse to the homosexual individual who - due to his or her sexual orientation - is refused employment, accommodation or restaurant service at the outset. Third, if the common law remedies for "breach of contract" recommended by McClung J.A. were, in fact, effective and salutary correctives, one is left to speculate as to why the legislature felt the need to protect others, so as to prohibit discrimination on the basis of colour, creed, and gender, for example. Indeed, Mr. Justice Kennedy for the majority in Romer comments on the difficulties historically encountered with common law remedies for discrimination in the United States, adding that "[i]n consequence, most States have chosen to counter discrimination by enacting detailed statutory schemes." ${ }^{149}$ Presumably there are also some prejudices in Alberta which the common law remedies are inadequate to address. Accordingly, it is difficult to understand Mr. Justice McClung's assumption that the homosexual community will be able to make better use of the private law remedies for discriminatory conduct than any other groups which have been the subject of discrimination in Alberta.

\title{
G. REVIVING THE "BLISS" APPROACH TO TESTING DISCRIMINATION
}

Mr. Justice McClung rules that the IRPA, as written, applies equally to heterosexuals and homosexuals and as such, no discrimination can be made out on the face of the 
legislation. ${ }^{150}$ This is reminiscent of Mr. Justice Ritchie's pronouncement in Bliss $\mathbf{v}$. A.G. Canada ${ }^{151}$ that while there was a longer qualifying period for women claiming government unemployment benefits due to pregnancy than for other individuals, the $A c t$ did not discriminate against women. This is because, according to the now notorious decision of Mr. Justice Ritchie, if the impugned provision in the Unemployment Insurance Act

treats unemployed pregnant women differently from other unemployed persons, be they male or female, it is, it seems to me, because they are pregnant and not because they are women ... any equality between the sexes in this area is not created by legislation, but by nature. ${ }^{152}$

The Court determined, in upholding the legislation, that the Unemployment Insurance Act did not create any discrimination and further, that the $A c t$ itself was not sex-based, but pregnancy-based.

As Professor Sheilah Martin comments, the court's reasoning in Bliss,

confuses the dictates of biology with the choices of the legislature. Laws cannot alter the inherent reproductive capacities of men and women, but they can and do prescribe the social and legal consequences which attach to them. Biology may dictate that only women can become pregnant, but the legislature has a full range of options on how to treat pregnant women and Parliament, not nature, was responsible for the Unemployment Insurance Act, $197 I^{153}$

Fortunately, the reasoning in Bliss has been expressly rejected by the Supreme Court of Canada, in Brooks v. Canada Safeway. ${ }^{154}$ The unanimous Court, under the leadership of Chief Justice Dickson, held that an employer's disability plan discriminated against women as it provided significantly less favourable treatment for pregnant employees. In so doing, the Court adopted the Andrews definition of discrimination:

I would say then that discrimination may be described as a distinction, whether intentional or not but based on grounds relating to personal characteristics of the individual or group, which has the effect of imposing burdens, obligations, or disadvantages on such individual or group not imposed upon others, or which withholds or limits access to opportunities, benefits, and advantages available to other members of society. Distinctions based on personal characteristics attributed to an individual solely on the basis of association with a group will rarely escape the charge of discrimination, while those based on an individual's merits and capacities will rarely be so classed. ${ }^{\text {iss }}$

In sum, the court recognized the common sense proposition that discrimination on the basis of pregnancy is discrimination on the basis of sex. 
Justice McClung, regrettably, follows the discredited reasoning of Bliss. To say, as Mr. Justice McClung does, that the IRPA makes no distinction between homosexuals and heterosexuals and hence is not discriminatory, is to say, analogously, that the old Unemployment Insurance Act at issue in Bliss is not discriminatory because it makes no distinction between pregnant men and pregnant women. Put another way, the Supreme Court of Canada in Brooks tells us that if it is only pregnant women who are required to wait longer for benefits - because men do not get pregnant - then the legislation or plan at issue discriminates between men and women. Similarly, if it is only homosexuals who are fired from their jobs - because employers do not object to heterosexuality - then IRPA discriminates against homosexuals by failing to protect them. As the result of the common sense evidenced in Brooks, one can no more shield a statute from the charge of discrimination on the fortuity of something that cannot happen (pregnancy in men) than on the fortuity of something that does not happen (being fired for heterosexuality).

It is true, as McClung J.A. asserts, that the IRPA draws no distinction between heterosexuals and homosexuals. Gay Catholics are afforded as much protection under the IRPA as straight Jews, but only so long as the discrimination confronted is religionbased. Lesbian orientals can feel as safe as heterosexual whites so long as the bigotry is racially motivated. But when the discrimination is sexuality-based, gays and lesbians are forced endure homophobia without legal recourse under the IRPA. ${ }^{156}$

Furthermore, like the court in Bliss, Mr. Justice McClung is refusing to acknowledge the socio-political reality within which the impugned legislation operates. Only by virtue of this refusal can one say, with a free conscience, that the legislation in question does not discriminate against women (in Bliss) or homosexuals (in Vriend).

In further defense of the IRPA, Mr. Justice McClung notes that there is nothing in the IRPA that creates or invites discriminatory behaviour against homosexuals and as a result, the $A c t$ cannot be impugned. ${ }^{157}$ This is both untrue and irrelevant. The IRPA does not create homophobia any more than legislation in Plessy requiring blacks to ride in separate cars from whites created racism. The IRPA of 1996, like the American Jim Crow laws of the 19th century, perpetuates and validates the violation of human rights by ensuring the legal unimpeachability and longevity of homophobic social practices and institutions. It thereby fits within the test articulated by Iacobucci J. in Symes v. Canada $^{158}$ (quoted by Mr. Justice McClung in his judgment) because it contributes to

156 Madam Justice Hunt makes a similar observation, supra note 1 at 30.

157 Ibid. at 20.

158 Mr. Justice lacobucci states in Symes, supra note 117 at 764:

If the adverse effects analysis is to be coherent, it must not assume that a statutory provision [or the absence of one] has an effect which is not proved. We must take care to distinguish between effects which are wholly caused, or which are contributed to, by an impugned provision [or its absence] and those social circumstances which exist independently of such a provision.

The parenthetic references are additions to the test made by Justice McClung in Vriend, supra note 1 at 20 of his Reasons for Judgment. 
discrimination against gay and lesbians. Indeed, As Madam Justice Hunt writes in her dissent in Vriend:

I note that at 13 the trial judge said "the effect of the decision to deny homosexuals recognition under the legislation is to reinforce negative stereotyping and prejudice thereby perpetuating and implicitly condoning its occurrence." In my view this was a reasonable conclusion and one that would justify dismissing the appeal, if an "effects" analysis were to be used. ${ }^{159}$

In short, both Russell, J. and Hunt, J.A. recognized that silence, and the refusal to remedy human rights violations, can be as powerful and effective a validation as any legislative provision which expressly permits that violation.

\section{H. THE DIFFICULTIES IN DEFINING WHAT SEXUAL ORIENTATION MEANS}

McClung, J.A. says that he will make no comment about the Crown's concern that if the phrase "sexual orientation" were read into the IRPA, it might lead to judicial protection of commonly recognized deviant behaviour. ${ }^{160}$ Certainly, if there is no point in analysing this issue, then it may well be best to leave it alone. But McClung J.A. does not leave the matter alone at all because he goes on to say:

It is pointless to deny that the Dahmer, Bernardo and Clifford Robert Olsen prosecutions have recently heightened public concern about violently aberrant sexual configurations and how they find expression against their victims. ${ }^{161}$

That Mr. Vriend and these individuals should even be mentioned together on the same page does an outrageous injustice to Vriend, if only by the proximity of the association. This purported off-hand comment appears to give tacit approval to the Crown's position with respect to the unworkability of the phrase "sexual orientation," if it were to be included in the IRPA, and links Vriend's claim for its inclusion with the most aberrant crimes imaginable. ${ }^{162}$

\footnotetext{
$139 \quad$ Vriend, ibid. at 30.

Isi) Ibid. at 22.

161 lbid.
}

162 It is of some value to note that numerous provincial legislatures (New Brunswick, Nova Scotia, Quebec, Ontario, Manitoba, Saskatchewan, British Columbia and the Yukon) have no definitional difficulty with the phrase "sexual orientation" and include it as a prohibited ground of discrimination in their equivalents of the IRPA. Furthermore, the Law Society of Alberta does not have any problem with the phrase either. Chapter 1, Rule 8 of the Law Society of Alberta's Code of Professional Conduct states:

A lawyer must not discriminate against any person on the basis of race, creed, colour, national or ethnic origin, gender, religion, marital status, sexual orientation, age, mental or physical disability or any similar personal attribute [emphasis added].

The Commentary to the Rules goes on to indicate that this prohibition applies to employment situations. 


\section{CONCLUSIONS}

The trial and appellate decisions in Vriend offer fascinating and troubling insights into the state of Charter analysis in Canadian jurisprudence, including struggles over the scope of conduct which attracts Charter application, the theoretical underpinnings for judicial review, retrenched and progressive notions of equality, and judicial responses to human rights violations.

Madam Justice Russell and Madam Justice Hunt recognized that sexual orientation is no less meritorious of protection than the colour of one's skin. They did so consciously, conscientiously, and on the basis of precedent, knowing that there was no other way to discharge the responsibility invested in them in acting as a court of competent jurisdiction under the Charter. Both reached the same conclusion that the $I R P A$ violates $\mathrm{s}$. 15 , a violation which cannot be saved by s. 1 , differing only on whether the better remedy would be to strike down the impugned sections of the IRPA or to read "sexual orientation" into the legislation in order to bring it into conformity with the Charter. ${ }^{163}$

McClung J.A., however, believed himself to be compelled to exercise extreme judicial deference to the legislative will of Alberta's elected representatives. This response, while conventional wisdom in a prior era, is no longer adequate.

I am in partial agreement with the conclusions of the trial judge. Specifically, I conclude that ss. $7(1), 8(1)$ and 10 of the IRPA violate s. 15(1) of the Charler and are not saved by s. 1 . In contrast to the trial judge, in my opinion the appropriate remedy here is not to read the words "sexual orientation" into the impugned sections. Instead, I would declare invalid the offending sections to the extent that they do not provide protection to homosexuals and suspend the declaration of invalidity for one year in order to allow the Legislature time in which to ensure that the legislation conforms with the Charter.

Justice Hunt's s. 15 analysis varies from that of the trial judge largely because it incorporates the subsequent analysis of the Supreme Court of Canada in three s. 15(1) decisions handed down since the Vriend matter went to trial. These decisions are Egan; Miron v. Trudel, supra note 119; and Thibaudeau v. Canada, [1995] 2 S.C.R. 627. 